\title{
FIELD AND LABORATORY TRIALS TO EVALUATE CERTAIN SINGLE AND TRIPLE CROSSES OF MAIZE HYBRIDS FOR THEIR RELATIVE SUSCEPTIBILITY TO SPIDER MITE Tetranychus urticae KOCH INFESTATION IN RELATION TO LEAVES PHYTOCHEMICAL CONSTITUENTS (ACARI: ACTENIDIDA: TETRANYCHIDAE) Mariam A. El-Sanady Plant Protection Research Institute, Dokki, Giza, Egypt
}

\begin{abstract}
Field and laboratory trials were carried out to evaluate six maize hybrids of each single and three-way crosses for their relative susceptibility to spider mite, Tetranychus urticae Koch infestation, in relation to leaves phytochemical analysis. Obtained data cleared that the triple hybrids were more infestation than single crosses hybrids during the course of study. The level infestation of single crosses hybrids could be divided into two categories; resistance and moderate infestation, while the triple crosses hybrids could be divided into three categories, moderate, susceptible and highly susceptible to spider mite infestation. Phytochemical components, the total carbohydrates, total protein, nitrogen, phosphorus and potassium were estimated and demonstrated that there were correlation between spider mite level infestation and leaves phytochemical constituents.
\end{abstract}

Keywords: Maize hybrids, spider mite, phytochemical analysis.

\section{INTRODUCTION}

Maize (Zea mays L.) occupies an important position among the cereal crops. It is considered one of the important strategic cereal crops in Egypt. It is widely used in bread making in rural areas of the country. It conforms the basis for several food industries such starch, fructose and corn oil, as well as the component of animal feed (maize for sillage including green maize and grain maize) there is a new utilization of maize as silage (with or without ears), Taha et al., (1994 a). Recently, the government policy is to mix wheat flour ( $80 \%)$ with corn flour $(20 \%)$ in bread making allover the country in order to reduce the imports of wheat grains. The annual national demand of maize is about 9.0 million tons, which is more than the total national production by about three million tons, these imported annually, therefore, it is advisable to encourage farmers towards planting maize especially in the new reclaimed lands. The cultivated area of maize is about 2 million feddan annually planted in summer season which competition with other summer crops. Spider mite considered one of the main pests infesting field crops and cause sever crop losses in Egypt. Taha et al., (1994 a, b) and Saweries (1993), Baker and Connell (1963) reported that spider mites damage the protective leaf surface and may inject toxic substance into the leaf and interfere with vital possesses. Dahms (1972) identified 16 possible criteria to evaluate pest tolerance in plants among which are the number of motile stages of pest attracted to plant when given a free choice, the length of developmental stages, fecundity or number of eggs laid by female, leaves components and thickness of cuticle epidermis of upper and lower surface of 
plant leaves. The aim of the present study is to estimate the relative susceptibility of some local maize single and triple crosses hybrids to spider mite, Tetranychus urticae Koch infestation in relation to some phytochemical analysis of leaves constituents

\section{MATERIALS AND METHODS}

Field and laboratory studies were carried out to evaluate (6 single and 6 triple crosses) of maize hybrids locally developed by Maize Research Program, Maize Res. Dept . Field Crops Res. Institute (ARC) namely:

1-Single Cross (SC) hybrids: Sc10, Sc125, Sc128, Sc129, Sc155 and Sc162.

2-Three-Way Crosses (TWC) hybrids :TWC 310, TWC 311, TWC 314 , TWC 327 , TWC 329 and TWC 352

\section{Field experiment:}

An area a of 1.2 feddan $\left(50.4 \times 100 \mathrm{~m}=5040 \mathrm{~m}^{2}\right)$ was chosen , prepared for cultivation and divided into equal 12 plots each of $4.2 \times 100 \mathrm{~m}$ .each plot divided into four replicates each of $\left(4.2 \times 25 \mathrm{~m} .=105 \mathrm{~m}^{2}\right)$. The space between rows $0.7 \mathrm{~m}$ ( 6 rows / plot) between hills $0.3 \mathrm{~m}$ (about 330 hills / row) one plant each hill by one side. Experiment was kept free from any pesticides application during the period of investigation. The normal agricultural practices were carried out as recommended. Maize seeds were sewing on May 21, 2011.

\section{Sampling for natural infestation rate estimation}

Twenty five days post plantation, samples were collected 10 days intervals till the end of season, samples put in paper bages, transferred to laboratory for examination using stereoscopic binocular microscope 10 leaves per replicate (40 leaves / hybrid), eggs and motile stages of spider mite Tetranychus urticae Koch were counted in two sq. inches lower surface of each leaf.

\section{Photochemical analysis of leaves maize hybrids}

A sample of each maize hybrids were collected, transferred to laboratory, cleaned, washed with distilled water and dried in an oven at $60{ }^{\circ} \mathrm{C}$ for $72 \mathrm{~h}$. then grinded into fine powder. Some specific phytochemical constituents of each maize hybrids leaves dry weight were determined as follows:

1- Total carbohydrates were extracted from the plant leaves and prepared to assay according to Aggour et al., (2001).

2-Total protein contents were determined using Kjeldatherm according to Knight et al., (1972).

3-Total nitrogen was determined by distillation in micro-kjeldahi apparatus (Chapman and Praft, 1961).

4- Total potassium was determined using the flame photometer according to (Dewis and Freites, 1970).

5- Total phosphorus was calorimetrically determined according (Murphy \& Riebly 1962). 


\section{RESULTS AND DISCUSSION}

To evaluate the relative susceptibility of six single and six three-way crosses of maize hybrids to spider mite, Tetranychus urticae infestation three criteria were taken into consideration, the average number of eggs, motile stage of spider mites infesting each hybrid during the seasons and phytochemical analysis of some leaves constituents. As shown in tables (1, 2, 3 \&4) obtained data and statistical analysis revealed that there were highly significant differences between maize hybrids in their relative susceptibility to spider mite, T. urticae infestation during the season 2011 at Beni_Suef Governorate, whereas, the population of spider mites started in few numbers after 25 days of sowing date on all tested single and triple crosses of maize hybrids, with definite trend, whereby the population of eggs and motile stages increased gradually until reached its peak during the last week of July according to each hybrid, after that the number of eggs and motile stages decreased gradually until the end of season. The level infestation of spider mites throughout the season was demonstrated that the six single cross hybrids could be divided according to the obtained data and statistical analysis into two categories; resistance and moderate of leaf infestation. Obtained results as shown in Tables (1\&2) revealed that single cross hybrids SC 155 and SC 162 was moderate infestation because of the average number of mites was (4.40 \& 4.60) individuals / 2 sq. inch. While the rest single hybrids were resistance to mite infestation, with rating $1.80,2.15,2.88$ and 3.15 mites / 2 sq. inch, while, the three-way crosses hybrids (TWC) could be divided into according to the obtained data and statistical analysis into three categories; moderate, susceptible and highly susceptible to spider mite, T. urticae infestation whereas, TWC 310 and TWC 329 were moderate infestation, which aggregated a total number of eggs and motile stages ( 1556.5 \&1433.0) and (1731.9 \& 1638.9) with rating infestation (4.5 \&5.1) mites / 2 sq. inch, respectively. The triple crosses TWC 314 and TWC 311 were susceptible to mite infestation; therefore, they received an average numbers during the season (2002.5 and 2476.0) motile stages, with rating infestation 6.25 and 7.73 mites / 2 sq. inch. On the other hand TWC 352 and TWC 327 were highly susceptible to infestation, whereby, they harbored an average numbers of eggs and motile stages (2559.0 \&3620.8) and (2785.6 \&3845.4) mites during the season, with rating infestation of 11.32 and 12.01 movable stages / 2 sq. inch, Tables (3 \&4).

These results coincided with that obtained by Taha et al., (1994a \&b) who evaluated certain maize hybrids to spider mite, $T$. urticae and the greater sugar-cane borer Sesamia cretica infestation, Azouz (2005) who studied the relative susceptibility of some single and triple crosses of maize plants to spider mite, T. urticae infestation.

Phytochemical analysis of leaves for each single and triple of maize hybrids:

The phenomenon of plant resistance to pests is quality that enables the plant to avoid, tolerate or recover from the effect of pests that would cause greater damage to other verities of the same species under similar conditions. Phytochemical components of the total carbohydrates, total 
protein, nitrogen, phosphorus and potassium were estimated. As shown in Tables (5 \&6) data and statistical analysis cleared that the total carbohydrates ranged between $9.65 \mathrm{mg} /$ dry wegight for resistance single crosses hybrids to $13.82 \mathrm{mg} / \mathrm{gm}$ to for intermediate single crosses, while, its range between $13.55 \mathrm{mg} / \mathrm{gm}$ dry weight for intermediate tree way crosses hybrids to $15.75 \mathrm{mg} / \mathrm{gm}$ for highly susceptible triple crosses whereas, carbohydrates accelerate reproduction of spider mites (Henneberry, 1962a).The quantities of total protein were small compare with that of total carbohydrates, the small amounts of protein were found in leaves of single cress SC10 and the triple hybrid, TWC 310, Tables (5\&6). The population of spider mite, T. urticae increased as nitrogen and phosphorus increased, while the opposite occurred with potassium, Tables $(2,4,5 \& 6)$. These results coincided with that obtained with El-Sanady (2008), Yokama (1978), Taha and El-Raies (1996) and Zaher and Hanna (1980).

Table (1):-Evaluation six single cross hybrids of maize for their relative susceptibility to spider mite $T$. urticae infestation (No. of eggs) at Beni- Suef Governorate during the season 2011.

\begin{tabular}{|l|c|c|c|c|c|c|}
\hline \multirow{2}{*}{$\begin{array}{l}\text { Inspection } \\
\text { date }\end{array}$} & \multicolumn{7}{|c|}{ Average No. of eggs / 80 sq. inches } \\
\cline { 2 - 7 } & SC10 & SC128 & SC129 & SC125 & SC155 & SC162 \\
\cline { 2 - 7 } & 12.8 & 13.8 & 33.0 & 40.3 & 59.9 & 77.3 \\
\hline June 15 & 15.9 & 19.2 & 53.2 & 58.2 & 98.1 & 157.1 \\
\hline June 25 & 38.5 & 53.3 & 80.6 & 120.7 & 194.1 & 216.0 \\
\hline July 5 & 190.7 & 207.0 & 190.1 & 260.0 & 303.9 & 352.9 \\
\hline July 15 & 212.5 & 240.0 & 352.2 & 284.1 & 366.8 & 406.0 \\
\hline July 25 & 259.7 & 252.6 & 338.1 & 424.0 & 500.2 & 531.2 \\
\hline Aug. 4 & 140.4 & 154.3 & 189.8 & 176.3 & 340.9 & 301.2 \\
\hline Aug. 14 & 72.0 & 67.5 & 129.2 & 161.6 & 127.9 & 175.0 \\
\hline Aug. 24 & 942.5 & 1007.7 & 1366.2 & 1525.2 & 1991.8 & 2216.7 \\
\hline Total & 117.1 & 125.9 & 170.8 & 190.7 & 248.9 & 277.1 \\
\hline Mean & \multicolumn{7}{|c|}{127.71 (Hybrids) } \\
\hline L.S.D. (5\%) & \multicolumn{7}{|c|}{170.75 ( Hybrids) } \\
\hline L.S.D.(1\%) & \multicolumn{7}{|c|}{} \\
\hline
\end{tabular}

Table (2):- Evaluation six single cross hybrids of maize for their relative susceptibility to spider mite $T$. urticae infestation (No. of motile stages) at Beni- Suef Governorate during the season 2011.

\begin{tabular}{|c|c|c|c|c|c|c|}
\hline \multirow{3}{*}{$\begin{array}{l}\text { Inspection } \\
\text { date }\end{array}$} & \multicolumn{6}{|c|}{ Hybrids } \\
\hline & \multicolumn{6}{|c|}{ Average No. of motile stages / 80 sq. inches } \\
\hline & SC10 & SC128 & SC129 & SC125 & SC155 & SC162 \\
\hline June 15 & 8.0 & 10.6 & 27.5 & 28.8 & 42.2 & 51.5 \\
\hline June 25 & 10.6 & 12.8 & 38.0 & 41.6 & 78.4 & 92.4 \\
\hline July 5 & 27.5 & 31.2 & 67.2 & 70.7 & 128.2 & 135.0 \\
\hline July 15 & 112.2 & 138.0 & 146.2 & 162.3 & 178.8 & 181.1 \\
\hline July 25 & 141.8 & 150.0 & 207.2 & 189.4 & 204.5 & 290.0 \\
\hline Aug. 4 & 162.3 & 168.4 & 225.4 & 265.0 & 392.6 & 354.1 \\
\hline Aug.14 & 82.6 & 81.2 & 118.6 & 135.6 & 238.5 & 256.3 \\
\hline Aug .24 & 55.4 & 48.5 & 92.3 & 115.4 & 105.4 & 111.8 \\
\hline Total & 600.4 & 690.7 & 922.4 & 1008.8 & 1409.2 & 1472.2 \\
\hline Mean & 75.1 & 80.1 & 115.3 & 126.1 & 158.8 & 184.02 \\
\hline L.S.D. (5\%) & \multicolumn{6}{|c|}{81.47 (Hybrids) } \\
\hline L.S.D.(1\%) & \multicolumn{6}{|c|}{108.92 (Hybrids) } \\
\hline
\end{tabular}


Table (3):-Evaluation six three- way cross hybrids of maize for their relative susceptibility to spider mite $T$. urticae infestation (No. of eggs) at Beni- Suef Governorate during the season 2011.

\begin{tabular}{|l|c|c|c|c|c|c|}
\hline \multirow{2}{*}{$\begin{array}{l}\text { Inspection } \\
\text { date }\end{array}$} & \multicolumn{7}{|c|}{ Average No. of eggs / 80 sq. inches } \\
\cline { 2 - 7 } & TWC310 & TWC329 & TWC314 & TWC311 & TWC352 & TWC327 \\
\hline June 15 & 14.4 & 25.0 & 48.6 & 35.0 & 60.0 & 66.7 \\
\hline June 25 & 16.8 & 44.5 & 66.2 & 97.4 & 101.4 & 120.4 \\
\hline July 5 & 94.4 & 101.2 & 112.8 & 168.4 & 231.5 & 252.5 \\
\hline July 15 & 168.5 & 194.3 & 220.0 & 285.0 & 340.0 & 378.5 \\
\hline July25 & 320.0 & 345.0 & 350.4 & 398.5 & 481.2 & 499.0 \\
\hline Aug. 4 & 394.4 & 408.8 & 418.5 & 428.6 & 614.4 & 680.8 \\
\hline Aug. 14 & 312.2 & 344.5 & 388.6 & 395.2 & 415.1 & 412.4 \\
\hline Aug. 24 & 225.8 & 268.6 & 292.4 & 284.2 & 314.8 & 375.3 \\
\hline Total & 1556.5 & 1731.9 & 1897.5 & 2092.3 & 2559.0 & 2785.6 \\
\hline Mean & 194.6 & 216.5 & 327.2 & 261.5 & 319.9 & 348.2 \\
\hline L.S.D. (5\%) & \multicolumn{7}{|c|}{165.32 (Hybrids) } \\
\hline L.S.D.(1\%) & \multicolumn{7}{|c|}{221.02 (Hybrids) } \\
\hline
\end{tabular}

Table (4):-Evaluation six three- way cross hybrids of maize for their relative susceptibility to spider mite $T$. urticae infestation (No. of motile stages) at Beni- Suef Governorate during the season 2014.

\begin{tabular}{|l|c|c|c|c|c|c|}
\hline \multirow{2}{*}{$\begin{array}{l}\text { Inspection } \\
\text { date }\end{array}$} & \multicolumn{7}{|c|}{ Hybrids } \\
\cline { 2 - 7 } & \multicolumn{7}{|c|}{ Average No. of motile stages / 80 sq. inches } \\
\cline { 2 - 7 } & TWC310 & TWC329 & TWC314 & TWC311 & TWC352 & TWC327 \\
\hline June 15 & 32.2 & 38.6 & 29.7 & 45.4 & 62.4 & 72.5 \\
\hline June 25 & 58.6 & 92.1 & 85.4 & 120.3 & 123.2 & 135.4 \\
\hline July 5 & 102.4 & 182.6 & 195.0 & 269.5 & 396.8 & 445.6 \\
\hline July 15 & 212.4 & 248.8 & 272.5 & 340.0 & 484.5 & 510.5 \\
\hline July 25 & 250.1 & 305.5 & 344.2 & 433.8 & 682.4 & 795.9 \\
\hline Aug. 4 & 288.4 & 320.2 & 450.0 & 514.5 & 718.1 & 798.4 \\
\hline Aug. 14 & 182.3 & 264.5 & 351.3 & 440.1 & 665.2 & 652.1 \\
\hline Aug. 24 & 124.2 & 186.8 & 274.4 & 312.4 & 482.2 & 485.0 \\
\hline Total & 1433.0 & 1638.9 & 2002.5 & 2476.0 & 3620.6 & 3845.4 \\
\hline Mean & 179.1 & 204.9 & 250.3 & 309.5 & 452.6 & 480.6 \\
\hline L.S.D. (5\%) & \multicolumn{7}{|c|}{184.37 (Hybrids) } \\
\hline L.S.D.(1\%) & \multicolumn{7}{|c|}{246.49 (Hybrids) } \\
\hline
\end{tabular}


Table (5 ):- Phytochemical analysis of leaves dry weight of six single crosses of maize hybrids.

\begin{tabular}{|c|c|c|c|c|c|c|}
\hline \multirow{2}{*}{ Rybrids } & \multirow{2}{*}{\begin{tabular}{|c|} 
Average \\
No. of \\
mites/ 80 \\
Sq. inch.
\end{tabular}} & \multicolumn{5}{|c|}{ Concrntration of phytochemical components } \\
\hline & & $\begin{array}{l}\mathbf{N} \\
\%\end{array}$ & $\begin{array}{l}\mathbf{P} \\
\%\end{array}$ & $\begin{array}{l}\mathrm{K} \\
\%\end{array}$ & $\begin{array}{c}\text { T. carbohydrtes } \\
\mathrm{mg} / \mathrm{gm}\end{array}$ & $\begin{array}{l}\text { T. protein } \\
\mathrm{mg} / \mathrm{gm}\end{array}$ \\
\hline SC10 & 70.10 & 1.95 & 0.50 & 2.42 & 9.65 & 4.25 \\
\hline SC128 & 80.10 & 1.99 & 0.92 & 2.11 & 11.74 & 4.81 \\
\hline SC129 & 111.30 & 2.24 & 0.96 & 2.01 & 12.45 & 5.56 \\
\hline SC125 & 126.10 & 2.42 & 1.20 & 1.95 & 14.56 & 5.62 \\
\hline SC155 & 157.20 & 2.81 & 1.24 & 1.82 & 13.56 & 5.84 \\
\hline SC162 & 184.02 & 3.00 & 1.50 & 1.80 & 13.82 & 6.65 \\
\hline Total & 728.82 & 14.41 & 6.32 & 12.11 & 75.78 & 32.72 \\
\hline Mean & 121.47 & 2.40 & 1.05 & 2.01 & 12.63 & 5.45 \\
\hline L.S.D. $(5 \%)$ & \multicolumn{6}{|c|}{21.19 (Hybrids) } \\
\hline L.S.D. $(1 \%)$ & \multicolumn{6}{|c|}{28.53 (Hybrids) } \\
\hline
\end{tabular}

Table (6 ):- Phytochemical analysis of leaves dry weight of six threeway crosses of maize hybrids.

\begin{tabular}{|c|c|c|c|c|c|c|}
\hline \multirow{2}{*}{ Hybrids } & \multirow{2}{*}{\begin{tabular}{|c} 
Average \\
No. of \\
mites/ 80 \\
Sq. inch.
\end{tabular}} & \multicolumn{5}{|c|}{ Concrntration of phytochemical components } \\
\hline & & $\begin{array}{l}\mathbf{N} \\
\%\end{array}$ & $\begin{array}{l}\mathbf{P} \\
\%\end{array}$ & $\begin{array}{l}\mathrm{K} \\
\%\end{array}$ & $\begin{array}{c}\text { T. carbohydrtes } \\
\mathrm{mg} / \mathrm{gm}\end{array}$ & $\begin{array}{c}\text { T. protein } \\
\text { mg/ gm }\end{array}$ \\
\hline TWC310 & 189.10 & 3.00 & 1.62 & 2.85 & 13.55 & 5.55 \\
\hline TWC329 & 204.90 & 3.15 & 1.75 & 2.44 & 13.78 & 5.04 \\
\hline TWC314 & 250.30 & 3.42 & 1.84 & 2.10 & 14.84 & 6.00 \\
\hline TWC311 & 309.50 & 3.50 & 1.88 & 1.92 & 14.42 & 5.45 \\
\hline TWC352 & 452.50 & 4.12 & 1.95 & 1.56 & 15.62 & 5.63 \\
\hline TWC327 & 480.60 & 4.45 & 1.98 & 1.38 & 15.75 & 4.80 \\
\hline Total & 1886.9 & 21.61 & 11.02 & 10.81 & 87.96 & 32.47 \\
\hline Mean & 314.48 & 3.60 & 1.84 & 1.80 & 14.66 & 5.41 \\
\hline L.S.D.(5\%) & \multicolumn{6}{|c|}{60.33 (Hybrids) } \\
\hline L.S.D.(1\%) & \multicolumn{6}{|c|}{81.23 (Hybrids) } \\
\hline
\end{tabular}

\section{REFERENCES}

Aggour, A. R.; G. H. Rady; M. M. Kandil and H. A. Azouz (2001). Evaluation of some Phaseolus germplasm for resistance to the two spotted spider mite, Biological, histological and chemical studies. Proceeding of the second PI. Breed. Conf. Oct.2 ${ }^{\text {nd }}$. Assuit Univ., : 391- 410.

Azouz, H. A. (2005). Ecological and biological studies on some mites associated with cotton and some field crops in Beni-Suef Governorate. Ph. D. Thesis, Fac. Agric., Al-Azhar Univ.181 pp.

Baker, J. E. and W. A. Connel (1963). The morphology of mouth parts of Tetranychus atlanticus and observation on feeding by this mite on soybean. Ann. Soc. Am., 56: 733-736.

Chapman, H. D. and P. F. Praft (1961). Method of analysis for soil plants and water. Div. Agric. Sci., Univ. California. 
Dahms, H. G. (1972). Technique in evaluation and development of hot-plant resistance. J. Environ. Qual., 1: 254-255.

Dewis, J, and Freites (1970). Physiological methods of soil, plant and water analysis. Food Agric. Organization of the United Nations, Sorld Bull. No. 10

El-Sanady, Mariam, A; S. M. Soliman and Ahlam A. Younes (2008). Field and laboratory studies to evaluate five soybean varieties for their Relative susceptibility to the two spotted spider mite Tetranychus urticae Koch infestation (Acarina: Tetranychidae: Actenidida).Egypt,J.Agric.Res. Rev.,86(1):77-88

Hennebrry, T. J. (1962a). The effect of plant nutrition on the fecundity of two strains of the two spotted spider mite. J. Econ. Entomol., 55: 134-137.

Knight, J. A.; S. Anderson and M. R. James (1972). Chemical basis of sulfphosphovanilla reaction of estimation of total serum, lipids, Clinical chemistry, Vol. 18 No. 3; 199-202.

Murphy,J and J.P.Riely (1962) A modifiedsingle solution of the determination of phosphate in natural water.Chem .Acta.,27:31-36

Sawires, Z. R. (1993). Susceptibility of maize varieties to mite infestation and toxicity of natural oils to mites. Egypt. J. Agric. Res., 70 (1): 141-149.

Taha, H. A. and S.A.A. El-Raies (1996). Influence of water salinity irrigation on spider mite infestation and cotton leaves contents. Proceeding of Acarology Congress IX Ohio.U.S.A. vol. (1): 257-260.

Taha,H,A,,M,F,Abadear andS,M,Soliman(1994 a) Assessment certain local maizecultivars to spider mite Tetranycus urticae Koch infestation with influence of sowing date, locality and plant leaves contents Egypt.J. Agric.,Res. Rev.,74(2):82-94

Taha, H. A.; S. F. Abo El- Saad and M. F. El-Mtwally (1994 b). Evaluation of certain maize cultivars to the pink borer Sesamia cretica Led and influence of sowing data on infestation rate. Egypt. J. appl. Sci., 9 (9):296-303.

Yokama,V .Y.(1978)Relation of seasonal changes in extra flower nwctar and foliar protein and arthropod population in cotton .Environmental Ecology:7 (6):799-802.

Zaher, M.A. and M.A. Hanna (1980). Relative susceptibility of ten soybean varieties to mite infestation and probable causes of resistance. Proc. $1^{\text {st }}$ Conf. Plant Prot. Res. Inst. Vol. (3): 41-51. 


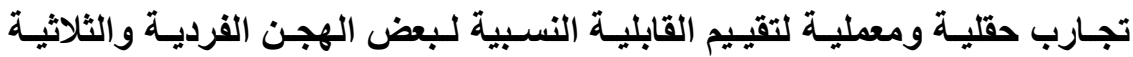
للاصـابة بـالعنكبوت الاحمـ Tetranychus urticae وعلاقته الفيا بالمحتويـات (Acari :Actinedida: Tetranychidae) الفيتوكيميائية

مريم عبدالرحمن السندى معهل بحوث وقاية النباتات ـ الاقى ـ الجيزة ـ مصر

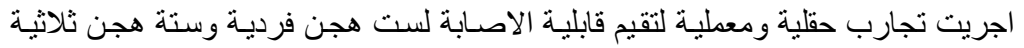

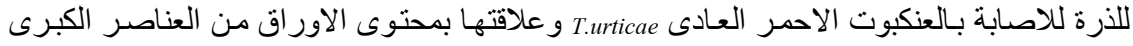

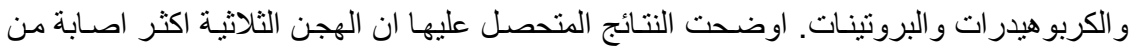

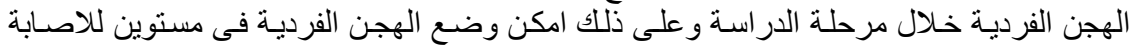

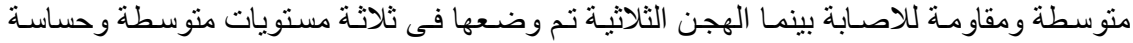

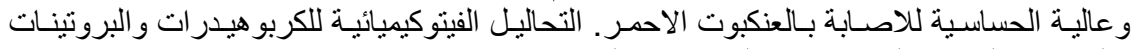

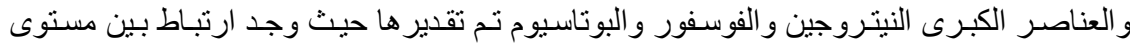

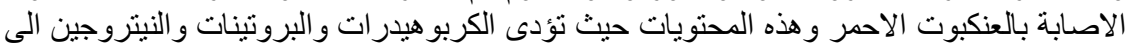

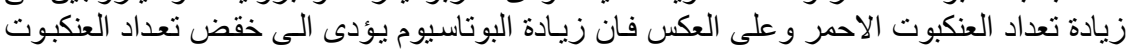

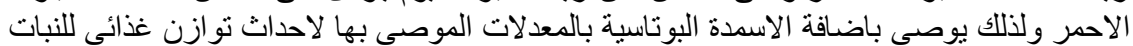
وخفض الاصابة بالافات الثاقبة الماصة. 